\title{
Analisis Kebutuhan Keluarga Berencana yang Tidak Terpenuhi (Unmet Need) pada Wanita Usia Subur
}

\section{Analysis of Unmet Need for Family Planning in Women of Childbearing Age}

\author{
Lanova Dwi Arde $\mathbf{M}^{1}$, Sri Novita Lubis ${ }^{2}$, Puteri Citra Cinta Asyura Nasution ${ }^{3}$ \\ Fakultas Kesehatan Masayarakat, Universitas Sumatera Utara, Indonesia
}

\section{ARTICLE INFO}

\section{Article history}

Received date

18 May 2021

Revised date

12 Jul 2021

Accepted date

25 Jul 2021

\section{Keywords:}

Family planning;

Contraception;

Childbearing age;

Unmet need.

\section{Kata kunci:}

Keluarga berencana;

Kontrasepsi;

Usia subur;

Unmet need.

\begin{abstract}
ABSTRAK
The high number of unmet needs affects the Total Fertility Rate (TFR) and birth spacing as well as the occurrence of unwanted pregnancies which also increases the risk of death in the mother. This study aims to analyze the unmet need for family planning in women of childbearing age in West Medan. This research is a quantitative study using a crosssectional study design. The research sample was women of childbearing age in Karang Berombak Village, West Medan, Medan City. Samples were taken in 7 neighborhoods with a simple random method. Data obtained a sample of 162 people. The research data were analyzed using statistical software with logistic regression methods. The results showed that the number of unmet needs in Karang Berombak Village was 24,7\%. Factors related to the incidence of unmet need, the decision to have $\mathrm{KB}$ is a decision by yourself/not involving the husband (Exp (B) 1,58 with a p-value of 0,02, after being controlled with the knowledge variable. The conclusion is that the number of unmet needs in Karang Village Wavy West Medan is still higher than the North Sumatra and the national rate. The factors that are associated with the incidence of unmet need are low levels of knowledge and the decision for family planning was the only women's decision/not involving the husband. It is recommended to related agencies be more active in socializing about family planning and its side effects so that there is no misunderstanding about family planning.
\end{abstract}

\begin{abstract}
Tingginya angka unmet need berpengaruh pada angka kelahiran (TFR) dan jarak kelahiran serta terjadinya kehamilan yang tidak diinginkan dan memicu terjadinya aborsi yang juga meningkatkan risiko kematian pada ibu. Penelitian ini bertujuan untuk menganalisis Kebutuhan Keluarga Berencana yang tidak terpenuhi (Unmet need) pada wanita usia subur di Medan Barat. Penelitian ini merupakan penelitian kuantitatif dengan menggunakan desain studi crossectional. Sampel penelitian adalah wanita usia subur di Kelurahan Karang Berombak, Medan Barat, Kota Medan. Sampel diambil di 7 lingkungan (rukun warga) dengan metode acak sederhana. Pengumpulan data di lapangan, diperoleh sampel 162 orang Data penelitian dianalisis menggunakan software statistik dengan metode regresi logistic. Hasil penelitian menunjukkan angka unmet need di Kelurahan Karang Berombak Medan Barat tinggi 24,7\%. Faktor yang berhubungan dengan dengan kejadian unmet need keputusan ber-KB yang merupakan keputusan sendiri/tidak melibatkan suami (Exp (B) 1,58 dengan nilai p-value 0,02, setelah dikontrol dengan variabel pengetahuan. Kesimpulan bahwa angka unmet need di Kelurahan Karang Berombak Medan Barat masih lebih tinggi dibandingkan angka Sumatera Utara dan nasional. Hasil analisis menunjukkan faktor yang berhubungan dengan dengan kejadian unmet need adalah tingkat pengetahuan yang rendah dan keputusan ber-KB yang merupakan keputusan sendiri/tidak melibatkan suami. Disarankan kepada kader dan instansi terkait untuk lebih aktif lagi mensosialisasikan tentang jenis KB dan efek sampingnya agar tidak ada kesalahpahaman pengetahuan pada WUS maupun pasangan atau suami tentang KB.
\end{abstract}




\section{PENDAHULUAN}

Indonesia merupakan negara dengan jumlah penduduk terbanyak nomor 4 di dunia setelah China, India, dan Amerika Serikat. Hasil Sensus Penduduk mencatat jumlah penduduk Indonesia pada tahun 2010 sebanyak 237,6 juta jiwa dengan rerata laju pertumbuhan penduduk periode 2000-2010 sebesar 1,49\%. Pemerintah telah mencanangkan beberapa program dalam mengendalikan jumlah penduduk, salah satunya adalah program Keluarga Berencana (KB), sehingga diharapkan laju pertumbuhan penduduk menurun. Salah satu indikator dalam menurunkan laju pertumbuhan penduduk adalah dengan menurunkan angka unmet need (BKKBN, BPS, Kemenkes, \& ICF Internasional, 2013; OJK, 2019).

Unmet need merupakan suatu kebutuhan akan alat kontrasepsi yang tidak terpenuhi. Wanita usia subur dikatakan unmet need jika ingin menunda kehamilan atau mengakhiri kehamilan untuk masa dua tahun berikutnya tetapi tidak menggunakan alat kontrasepsi. Unmet need merupakan salah satu angka yang menjadi salah satu target 3 zero case oleh BKKBN (OJK, 2019). Kelompok ini merupakan sasaran yang perlu mendapat perhatian serius mengingat mereka yang masih membutuhkan pelayanan KB namun belum terpenuhi, mengakibatkan kecenderungan kehamilan tidak diiinginkan (Rismawati, 2012).

Di Indonesia angka unmet need tahun 2017 mencapai $11 \%$ dengan $4 \%$ untuk penjarangan, $7 \%$ untuk pembatasan. Angka ini meningkat dibanding dari hasil survei sebelumnya tahun 2012 yaitu 8,6\% (BKKBN, BPS, Kemenkes, \& Internasional, 2018). Berdasarkan laporan kinera BKKBN tahun 2019, salah satu indikator kinerja sasaran adalah persentase unmet need, dengan target 9,91\% namun realisasinya 12,10\% (OJK, 2019). Angka unmet need Sumatera Utara berdasarkan SDKI 2017 sama dengan angka nasional yaitu sebesar $11 \%$. Berdasarkan analisis data RPJMN 2017 angka unmet need meningkat menjadi 37,5\% (Mutiara, Sitorus, \& Novita, 2020).

Tingginya angka unmet need berpengaruh pada angka kelahiran (TFR) dan jarak kelahiran. Di Sumatera Utara TFR tahun 2017 adalah 2,9, artinya rata-rata jumlah anak yang dilahirkan seorang wanita selama masa usia suburnya di Sumatera Utara adalah 3 orang. Angka ini masih tinggi dibandingkan TFR nasional yaitu 2,4. Untuk jarak kelahiran, di Sumatera Utara sekitar $20 \%$ kelahiran memiliki jarak kurang dari 2 tahun dari kelahiran sebelumnya. Rapatnya jarak kelahiran dan banyaknya anak yang dilahirkan sehingga berisiko tinggi terhadap kematian ibu dan bayi (BKKBN, et al., 2018). Selain itu dampak dari unmet need adalah terjadinya kehamilan yang tidak diinginkan juga memicu terjadinya aborsi yang juga meningkatkan risiko kematian pada ibu (Ratnaningsih, 2018).

Terjadinya unmet need dipengaruhi oleh beberapa faktor. Hasil penelitian Ali dan Okud menunjukkan bahwa yang banyak unmet need adalah wanita dengan tingkat pendidikan rendah, dipengaruhi juga oleh tingkat pendidikan suami dan status pekerjaan wanita (Ali \& Okud, 2013). Dwi, et al. membuktikan faktor yang berhubungan dengan unmet need $\mathrm{KB}$ adalah sikap, akses jenis dan kualitas layanan kesehatan dan akses PUS mendapatkan informasi (Dwi, et al., 2014). Sedangkan hasil penelitian Fadhila, et al (2017) menunjukkan dukungan suami berhubungan dengan terjadinya unmet need .

Beberapa penelitian tentang unmet need sudah dilakukan di Sumatera Utara, namun untuk wilayah Kelurahan Karang Berombak, Medan Barat belum ada yang menganalisis tentang gambaran kejadian unmet need dan faktor yang berhubungan dengan kejadian tersebut, sehingga menjadi penguat dilakukannya studi ini.

\section{METODE}

Penelitian ini merupakan penelitian kuantitatif dengan menggunakan desain studi cross sectional. Responden diwawancara dengan panduan kuesioner. Kuesioner yang digunakan dalam penelitian ini dibangun dengan mengacu ke pertanyaan pada kuesioner survei nasional. Penelitian dilakukan pada bulan April smpai dengan November 2019.

Populasi penelitian ini adalah semua wanita usia subur di Kelurahan Karang Berombak, Medan Barat, Kota Medan. Sampel penelitian adalah wanita usia subur yang sudah menikah dan masih dalam ikatan pernikahan. Jumlah sampel dihitung menggunakan rumus sampel beda proporsi Lameshow, dan hasil perhitungan didapatkan jumlah sampel minimal penelitian sebesar 135 responden. Sampel diambil di 7 dari 19 lingkungan (rukun warga) yang ada di Kelurahan Karang Berombak dengan metode pengambilan sampel menggunakan cluster lingkungan dan proporsional random sampling dalam menentukan sampel individu. Dari pengumpulan data di lapangan, diperoleh sampel 162 orang. Data penelitian dianalisis menggunakan software statistik dengan metode regresi logistik. Penelitian ini telah memiliki Surat Persetujuan Komisi Etik Penelitian Kesehatan yang dikeluarkan oleh Fakultas Keperawatan USU dengan nomor 1835/V/SP/2019. 
HASIL

Tabel 1. Gambaran Karakteristik dan Sosio Ekonomi Responden

\begin{tabular}{|c|c|c|}
\hline Variabel & Jumlah & $\%$ \\
\hline \multicolumn{3}{|c|}{ Pendidikan Terakhir Responden } \\
\hline SD & 14 & 8,6 \\
\hline SMP & 30 & 18,5 \\
\hline SMA & 96 & 59,3 \\
\hline Akademi/D3 & 8 & 4,9 \\
\hline $\mathrm{S} 1 / \mathrm{S} 2$ & 14 & 8,6 \\
\hline \multicolumn{3}{|c|}{ Pendidikan Terakhir Suami } \\
\hline SD & 11 & 6,8 \\
\hline SMP & 31 & 19,1 \\
\hline SMA & 98 & 60,5 \\
\hline Akademi/D3 & 6 & 3,7 \\
\hline $\mathrm{S} 1 / \mathrm{S} 2$ & 16 & 9,9 \\
\hline \multicolumn{3}{|c|}{ Pendapatan keluarga } \\
\hline$<$ UMR & 83 & 51,2 \\
\hline$\geq \mathrm{UMR}$ & 79 & 48,8 \\
\hline \multicolumn{3}{|l|}{ Paritas } \\
\hline$>2$ & 102 & 63,0 \\
\hline$\leq 2$ & 60 & 37,0 \\
\hline \multicolumn{3}{|l|}{ Memiliki Balita } \\
\hline Ya & 96 & 59,2 \\
\hline Tidak & 66 & 40,8 \\
\hline Unmet need & 40 & 24,7 \\
\hline Menunda & 9 & 22,5 \\
\hline Membatasi & 31 & 77,5 \\
\hline Met & 122 & 75,3 \\
\hline
\end{tabular}

Sebagian besar responden penelitian berpendidikan terakhir SMA (59,35), selanjutnya yang berpendidikan SMP 18,5\%, berpendidikan SD dan S1/S2 menunjukkan proporsi yang sama yaitu $8,6 \%$ dan proporsi yang paling rendah adalah berpendidikan akademi. Gambaran distribusi pendidikan suami responden juga tidak jauh dari gambaran responden. Paling banyak memiliki latar belakang pendidikan SMA yaitu sebesar 60,5\%. Selanjutnya diikuti berpendidikan SMP sebanyak 19,2\%, S1/S2 $9,9 \%$, SD $6,8 \%$, dan yang paling rendah berpendidikan akademi sebanyak $3,7 \%$.

Gambaran sosial ekonomi responden dilihat dari jumlah pendapatan keluarga yaitu gabungan pendapatan suami dan istri didapatkan bahwa $51 \%$ pendapatan keluarga responden berada di bawah UMR Kota Medan.Berdasarkan jumlah anak, sebanyak $63 \%$ responden memiliki anak lebih dari 2.Sekitar 59\% responden memiliki anak balita dalam rumah tangga.

Dari hasil analisis didapatkan sebanyak 40 $(24,7 \%)$ responden memilih unmet need. Diantara 40 yang unmet need, $78 \%$ diantaranya membatasi kelahiran, dan $22 \%$ lainnya karena ingin menunda punya anak.

Tabel 2.Hasil Tabulasi Silang Unmet Need dengan Faktor Risiko

\begin{tabular}{|c|c|c|c|c|c|c|}
\hline \multirow{2}{*}{ Variabel } & \multicolumn{2}{|c|}{ Unmet need } & \multicolumn{2}{|c|}{ Met need } & \multirow{2}{*}{ OR $(95 \% \mathrm{CI})$} & \multirow{2}{*}{ p-value } \\
\hline & $\mathbf{n}$ & $\%$ & $\mathbf{n}$ & $\%$ & & \\
\hline \multicolumn{7}{|l|}{ Usia } \\
\hline$\leq 35$ & 16 & 19,5 & 66 & 80,5 & \multirow{2}{*}{$0,57(0,2-1,17)$} & \multirow[t]{2}{*}{0,172} \\
\hline$>35$ & 24 & 30,0 & 56 & 70,0 & & \\
\hline \multicolumn{7}{|l|}{ Pendidikan WUS } \\
\hline Rendah & 33 & 23,6 & 107 & 76,4 & \multirow[t]{2}{*}{$0,66(0,25-1,76)$} & \multirow[t]{2}{*}{0,570} \\
\hline Tinggi & 7 & 31,8 & 15 & 68,2 & & \\
\hline \multicolumn{7}{|l|}{ Pendidikan suami } \\
\hline Rendah & 34 & 24,3 & 106 & 75,7 & \multirow[t]{2}{*}{$0,86(0,31-2,36)$} & \multirow[t]{2}{*}{0,971} \\
\hline Tinggi & 6 & 27,3 & 16 & 72,7 & & \\
\hline \multicolumn{7}{|l|}{ Pendapatan keluarga } \\
\hline < UMR & 26 & 21,3 & 96 & 78,7 & \multirow[t]{2}{*}{$0,50(0,23-1,10)$} & \multirow[t]{2}{*}{0,126} \\
\hline$\geq \mathrm{UMR}$ & 14 & 35,0 & 26 & 65,0 & & \\
\hline \multicolumn{7}{|l|}{ Paritas } \\
\hline$>2$ & 29 & 28,4 & 73 & 71,6 & \multirow{2}{*}{$1,78(0,89-3,87)$} & \multirow[t]{2}{*}{0,211} \\
\hline$<=2$ & 11 & 18,3 & 49 & 81,7 & & \\
\hline \multicolumn{7}{|l|}{ Memiliki Anak Balita } \\
\hline $\mathrm{Ya}$ & 23 & 28,8 & 57 & 71,2 & \multirow[t]{2}{*}{$1,54(0,75-3,17)$} & \multirow[t]{2}{*}{0,317} \\
\hline Tidak & 17 & 10,7 & 65 & 79,3 & & \\
\hline \multicolumn{7}{|l|}{ Pengetahuan } \\
\hline Rendah & 18 & 36,0 & 32 & 64,0 & \multirow[t]{2}{*}{$2,31(1,09-4,83)$} & \multirow[t]{2}{*}{$0,042 *$} \\
\hline Tinggi & 22 & 19,6 & 90 & 80,4 & & \\
\hline \multicolumn{7}{|l|}{ Keputusan ber-KB } \\
\hline Sendiri & 21 & 40,4 & 31 & 59,6 & \multirow[t]{2}{*}{$3,23(1,54-6,82)$} & \multirow[t]{2}{*}{$0,003 *$} \\
\hline Hasil diskusi dengan suami & 19 & 17,3 & 91 & 82,7 & & \\
\hline
\end{tabular}

Hasil tabulasi silang antara unmet need dengan usia diperoleh wanita yang berusia 35 tahun kebawah 0,6 kali untuk unmet need dibandingkan yang berusia diatas 35 tahun, atau 
dengan kata lain wanita yang berusia diatas 35 tahun 1,7 kali lebih tinggi untuk unmet need dibandingkan yang berusia 35 tahun ke bawah.

Berdasarkan tingkat pendidikan, wanita yang berpendidikan rendah 0,7 kali lebih rendah untuk unmet need dibandingkan yang berpendidikan tinggi, atau bisa juga dijelaskan bahwa wanita yang berpendidikan tinggi 1,5 kali lebih tinggi memilih untuk unmet need dibandingkan wanita yang berpendidikan rendah.

Berdasarkan tingkat pendidikan suami, wanita yang memiliki suami dengan pendidikan rendah 0,9 kali untuk memilih unmet need dibandingkan yang memiliki suami dengan pendidikan tinggi. Artinya proporsi wanita yang unmet need berdasarkan latar belakang pendidikan suami hampir sama.

Berdasarkan pendapatan keluarga, wanita yang pendapatan keluarganya dibawah upah minimum regional (UMR) Kota Medan 0,5 kali lebih rendah untuk memilih unmet need dibandingkan yang pendapatan keluarganya di atas UMR. Atau dengan kata lain wanita yang pendapatan keluarganya diatas UMR cenderung 2 kali lebih tinggi untuk memilih unmet need dibandingkan yang pendapatan keluarganya dibawah UMR Kota Medan.

Berdasarkan jumlah anak, wanita yang memiliki anak lebih dari 2 memiliki kecenderungan 1,8 kali lebih tinggi untuk memilih unmet need dibandingkan yang memiliki anak hanya 2 atau kurang dari 2 orang.

Selanjutnya wanita yang masih memiliki anak usia balita dalam rumah tangga 1,5 kali lebih tinggi dalam memilih unmet need diabndingkan yang tidak memiliki anak usia balita.

Berdasarkan pengetahuan tentang jenis alat kontrasepsi, wanita dengan tingkat pengetahuan rendah cenderung 2,3 kali lebih tinggi untuk memilih unmet need dibandingkan dengan wanita yang tingkat pengetahuannya tinggi.

Analisis selanjutnya menunjukkan bahwa wanita yang dalam menentukan pilihan dalam ber-KB merupakan keputusan sendiri cenderung 3,2 kali lebih tinggi untuk memilih unmet need dibandingkan jika hal tersebut merupakan hasil diskusi dengan pasangan.

Tabel 3. Hasil Analsis Mulitivariat Unmet Need dengan Faktor Risiko

\begin{tabular}{l|r|c|c}
\hline \multicolumn{1}{c|}{ Variabel } & $\begin{array}{c}\text { Exp (B) } \\
(\mathbf{9 5 \%} \mathbf{C I})\end{array}$ & SE & p-value \\
\hline $\begin{array}{l}1,77 \\
\text { Pengetahuan }\end{array}$ & 0,40 & 0,151 \\
$\begin{array}{l}\text { Keputusan } \\
\text { ber-KB }\end{array}$ & $0,81-3,90$ & & 0,58 \\
$1,07-2,33$ & 0,20 & 0,020 \\
\hline
\end{tabular}

Selanjutnya hasil analisis multivariat menunjukkan variabel yang berhubungan dengan unmet need adalah keputusan ber-KB yang merupakan keputusan sendiri/tidak melibatkan suami (Exp (B) 1,58 dengan nilai p-value $(0,02)$, setelah dikontrol dengan variabel pengetahuan.

\section{PEMBAHASAN}

Unmet need merupakan suatu kebutuhan akan alat kontrasepsi yang tidak terpenuhi yang berdampak pada angka kelahiran (TFR), jarak kelahiran, dan terjadinya kehamilan tidak diinginkan. Unmet need dikelompokkan menjadi 2 yaitu untuk menjarangkan kelahiran dan untuk membatasi kelahiran (BKKBN, 2019)

Hasil penelitian menunjukkan 24,7\% memilih unmet need. Angka ini lebih tinggi dibandingkan angka nasional dan Sumatera Utara yang $11 \%$. Diantara responden yang unmet need, diantaranya adalah membatasi kelahiran dan karena ingin menunda punya anak. Hasil ini sejalan dengan penelitian yang dilakukan oleh Fadhila, et al. (2017) yang juga mendapatkan $22,5 \%$ unmet need untuk menjarakkan kehamilan dan $72,5 \%$ untuk membatasi jumlah anak (Fadhila, et al., 2017).

Beberapa alasan yang diungkapkan responden tidak menggunakan alat kontrasepsi sebagian besar adalah takut akan efek samping dari alat kontrasepsi yang pernah dilakukan, seperti bekas suntikan pernah bernanah, terjadi pembengkakan ditempat bekas suntikan dan badan menjadi gemuk. Selain itu, alasan lain yang diungkapkan tidak menggunakan alat kontrasepsi adalah suami tidak setuju, fasilitas kesehatan jauh, dan jarang melakukan hubungan seksual dengan suami.

Hasil penelitian menunjukkan bahwa WUS yang berumur diatas 35 tahun cenderung 1,75 kali lebih tinggi memilih unmet need dibandingkan yang berumur dibawah 35 tahun. Hasil ini tidak sejalan dengan penelitian yang dilakukan oleh George, et al. (2018) di Karnataka yang menunjukkan WUS di bawah 35 tahun cenderung 3 kali lebih tinggi untuk unmet need dibandingkan yang berumur ditas 35 tahun. Hal ini mungkin terjadi karena WUS pada lokus penelitian telah berumur di atas 35 tahun dan telah memiliki sejumlah anak sehingga mereka tidak ingin memiliki anak lagi karena jumlah anak yang lebih banyak akan membuat kecenderungan unmet need lebih tinggi. Hal ini menurut Odumosu dalam CICRED walaupun tidak ada penjelasan yang spesifik tentang umur dan kejadian unmet need, namun ada pemahaman 
dikalangan wanita bahwa umur di atas 35 menganggap dirinya tua dan masa reproduktif kecil sehingga peluang untuk hamil juga menjadi kecil (CICRED, 2005; George, T., Ramachandran, Peters, \& Kiran, 2018; Listyaningsih, Sumini, \& Satiti, 2016).

Berdasarkan latar belakang pendidikan baik pendidikan WUS maupun pendidikan suami menunjukkan bahwa responden dengan pendidikan tinggi cenderung lebih tinggi untuk unmet need dibandingkan yang berpendidikan rendah. Hasil ini tidak sejalan dengan penelitian Khalil, et al., di Arab Saudi dan Makonen dan Worku di Ethiopia Selatan.Mendapatkan pendidikan yang lebih tinggi memungkinkan WUS untuk mendapatkan pengetahuan tentang kontrasepsi yang berhubungan dengan kelahiran, kesakitan dan kematian ibu dan bayi (Khalil, Alzahrani, \& Siddiqui, 2018; Mekonnen \& Worku, 2011).

Responden dengan jumlah pendapatan keluarga diatas upah minimum rerata Kota Medan cenderung untuk unmet need dibandingkan yan pendapatannya di bawah UMR. Penelitian ini sejalan dengan yang dilakukan oleh Usman (2013) di Gorontalo dimana proporsi responden yang pendapatannya besar yang unmet need hampir 2 kali lebih besar dibandingkan pendapatannya yang kurang. Keadaan sosial ekonomi yang rendah biasanya berhubungan dengan masalah kesehatan salah satunya mempengaruhi pembiayaan pengobatan dan kontrasepsi. Usman menjelaskan kondisi ekonomi keluarga sangat mempengaruhi akses seseorang dalam memanfaatkan layanan kesehatan. Namun penelitian ini tidak sejalan dengan hal tersebut karena seperti yang dijelaskan responden saat wawancara bahwa mereka tidak menggunakan alat kontrasepsi umumnya bukan karena masalah ekonomi, tetapi karena masalah kesehatan dan takut akan efek samping dari alat kontrasepsi (Usman, 2013).

Selanjutnya, WUS yang memiliki anak lebih dari 2 cenderung 1,7 kali lebih tinggi unmet need dibandingkan yang anaknya hanya 2 atau kecil dari itu. Penelitian ini sejalan dengan penelitian Fadhila, et al., di Padang serta pendapat Listyaningsih, et al. bahwa jumlah anak yang besar mempengaruhi kecenderungan unmet need menjadi lebih tinggi. Dalam penelitian Ratnaningsih dijelaskan bahwa unmet need dapat terjadi pada wanita dengan jumlah anak yang banyak maupun sedikit. Hal ini tergantung kepada tujuannya apakah ingin menjarangkan atau mengakhiri kehamilan namun tidak mau menggunakan $\mathrm{KB}$ karena takut efek samping
(Fadhila, et al., 2017; Listyaningsih, et al., 2016; Ratnaningsih, 2018).

Berdasarkan pengetahuan tentang jenis alat kontrasepsi diketahui bahwa WUS yang memiliki pengetahuan rendah tentang alat kontrasepsi cenderung 2,3 kali lebih tinggi unmet need dibandingkanyang memiliki pengetahuan tinggi. Pengetahuan yang rendah dalam penelitian ini adalah responden yang hanya mengetahui beberapa jenis alat kontrasepsi dan efek samping dari masing-masing alat kontrasepsi. Kontrasepsi yang paling banyak diketahui adalah pil KB, KB suntik, IUD, dan Implan. Sedangkan untuk jenis alat KB yang hanya $65 \%$ mengetahui adalah vasektomi dan tubektomi.

Seperti yang dijelaskan dalam teori Green dalam Notoatmodjo (2010), salah satu faktor predisposisi adalah pengetahuan yang menjadi salah satu motivasi untuk berperilaku. Sehingga rendahnya pengetahuan responden akan alat kontrasepsi mempengaruhi perilaku mereka untuk ber-KB atau menjadi unmet need. Untuk hasil ini ini sejalan dengan penelitian Mutiara, et al., dan Ratnaningsh yang juga menunjukkan hasil adanya hubungan antara pengetahuan dengan keputusan unmet need (Notoatmodjo, 2010; Ratnaningsih, 2018).

Berdasarkan keputusan ber KB diketahui bahwa WUS yang keputusan ber-KB-nya adalah keputusan sendiri 3,23 kali lebih cenderung unmet need dibandingkan yang merupakan hasil diskusi dengan suami. Dari hasil wawancara didapatkan salah satu alasan wanita tidak berdiskusi dengan suami karena suami masih ingin punya anak, sedangkan sang istri sudah tidah mau hamil lagi. Hasil ini sejalan dengan penelitian yang dilakukan oleh George, et al. (2018) di Karnataka yang menyimpulkan bahwa wanita yang tidak mendikusikan tentang keluarga berencana dengan suami cenderung 6,61 kali lebih tinggi untuk unmet need dibandingkan berdiskusi dengan suami.

Nabila dan Nur dalam penelitiannya menjelaskan bahwa sebagian besar masyarakat Indonesia menganut budaya patrilineal. Hal ini secara tidak langsung manjadikan pria sebagai kepala keluarga yang bertanggung jawab atas keputusan yang diambil dalam rumah tangga. Sehingga pengetahuan dan pandangan suami tentang program keluarga berencana akan sangat berpengaruh terhadap keputusan pasangan dalam memilih suatu metode KB (George, et al., 2018; Nabila \& Nur, 2021). 


\section{SIMPULAN}

Angka unmet need di Kelurahan Karang Berombak Medan Barat masih lebih tinggi dibandingkan angka Sumatera Utara dan angka nasional. Sebagian besar unmet need terjadi pada WUS yang membatasi kelahiran atau yang tidak mau lagi memiliki anak. Alasan responden unmet need adalah karena takut akan efek samping alat kontrasepsi, suami tidak setuju, fasilitas kesehatan jauh dan jarang melakukan hubungan seksual dengan suami. Hasil analisis menunjukkan faktor yang berhubungan dengan

\section{DAFTAR PUSTAKA}

Ali, A. A. A., \& Okud, A. (2013). Factors affecting unmet need for family planning in Eastern Sudan. BMC Public Health, 13, 102. https://doi.org/10.1186/1471-245813-102

BKKBN. (2019). Survei Kinerja dan Akuntabilitas Program (SKAP 2019). Badan Kependudukan Dan Keluarga Berencana Nasional (BKKBN).

BKKBN, BPS, Kemenkes, \& ICF Internasional. (2013). Survei Demografi dan Kesehatan Indonesia

2012.

https://doi.org/10.1111/j.14710528.2007.01580.x

BKKBN, BPS, Kemenkes, \& Internasional, I. (2018). Survey Demografi dan Kesehatan Indonesia. https://doi.org/0910383107 [pii] \r10.1073/pnas.0910383107

CICRED. (2005). Reproductive Health, Unmet Needs and Poverty (S. Lerner \& E. Vilquin, Eds.). Paris: Committee for International Cooperation in National Resarch in Demography.

Dwi, W., Kartika, D., Kesehatan, F., Universitas, M., Dwi, W., Kartika, D., ... Universitas, M. (2014). Faktor yang Memengaruhi Unmet Need Keluarga Berencana. Jurnal Biometrika Dan Kependudukan, 4, 70-75. https://doi.org/10.1007/978-94-007-0723-8

Fadhila, N. H., Widoyo, R., \& Elytha, F. (2017). Unmed Need Keluarga Berencana Pada Pasangan Usia Subur Di Kecamatan Padang Barat Tahun 2015. Jurnal Kesehatan Masyarakat Andalas, 10(2), 151. https://doi.org/10.24893/jkma.v10i2.200

George, N., T., S., Ramachandran, A., Peters, A., \& Kiran, P. R. (2018). The unmet needs for family planning and its associated factors among ever married women in selected villages of Anekal taluk, dengan kejadian unmet need adalah tingkat pengetahuan yang rendah dan keputusan ber-KB yang merupakan keputusan sendiri/tidak melibatkan suami.

Disarankan kepada kader dan instansi terkait untuk lebih aktif lagi mensosialisasikan tentang jenis KB dan efek sampingnya agar tidak ada kesalahpahaman pengetahuan pada WUS maupun pasangan atau suami. Selain untuk meluruskan informasi terkait $\mathrm{KB}$, diharapkan suami istri bisa berdiskusi dan membuat keputusan terbaik tentang ber KB dalam keluarga mereka.

Karnataka: a community based cross sectional study. International Journal of Community Medicine And Public Health, 5(5), 2048. https://doi.org/10.18203/23946040.ijemph20181721

Khalil, S. N., Alzahrani, M. M., \& Siddiqui, A. F. (2018). Unmet need and demand for family planning among married women of Abha, Aseer Region in Saudi Arabia. Middle East Fertility Society Journal, 23(1), 31-36. https://doi.org/10.1016/j.mefs.2017.07.004

Listyaningsih, U., Sumini, S., \& Satiti, S. (2016). Unmet Need: Konsep Yang Masih Perlu Diperdebatkan. Populasi, 24(1), 72-90. https://doi.org/10.22146/jp.23696

Mekonnen, W., \& Worku, A. (2011). Determinants of low family planning use and high unmet need in Butajira District, South Central Ethiopia. Reproductive Health, 8(1), 1-8. https://doi.org/10.1186/1742-4755-8-37

Mutiara, E., Sitorus, A., \& Novita, S. (2020). Determinants of Unmet Need for Family Planning among Married Women Age 1549 in Sumatera Utara Province (Analysis of 2017 RPJMN Data). Indian Journal of Public Health. https://doi.org/10.4081/jphia.2020.1084

Nabila, D. T., \& Nur, D. (2021). Dukungan Suami dan Unmet Need KB Pada Wanita Pasangan Usia Subur ( WPUS ) Husband's Support and Unmet Needs Family Planning in Women of Fertile Age Couples ( WFAC ). Jurnal Bikfokes, 1. http://dx.doi.org/10.51181/bikfokes.v1i2.4 633

Notoatmodjo, S. (2010). Ilmu Perilaku Kesehatan. Jakarta: Rineka Cipta.

OJK. (2019). Laporan Kinerja 2019. Otoritas 
Jasa Keuangan,

https://www.ojk.go.id/id/data-dan-

$1-50$. statistik/laporan-kinerja/Pages/-LaporanKinerja-OJK-2019.aspx

Ratnaningsih, E. (2018). Analisis Dampak Unmet Need Keluarga Berencana Terhadap Kehamilan Tidak Diinginkan Di Rumah Sakit Panti Wilasa Citarum Semarang. Jurnal Kebidanan, 7(2), 80-94. http://jurnal.unimus.ac.id/index.php/jur_bid

Rismawati, S. (2012). Unmet Need: Tantangan Program KB dalam menghadapi ledakan penduduk 2030. [Tesis]. Bandung:
Magister Kebidanan Fakultas Kedokteran UNPAD Bandung. http://pustaka.unpad.ac.id/wpcontent/uploads/2014/10/ARTIKELUNMET-NEED.pdf

Usman, L. (2013). Analisis Faktor Determinan yang Berhubungan dengan Kejadian Unmet Need KB Pasangan Usia Subur Terhadap Kehamilan yang Tidak diinginkan di Kecamatan Kota Tengah Kota Gorontalo. [Tesis]. Makassar: Program Studi Kesehatan Masyarakat, Universitas Hasanuddin. 